\title{
At-sea distribution of foraging little auks relative to physical factors and food supply
}

\author{
Johanna E. H. Hovinen ${ }^{1,2,3, *}$, Jorg Welcker ${ }^{1}$, Ananda Rabindranath ${ }^{4}$, \\ Zachary W. Brown ${ }^{5,}{ }^{6}$, Haakon Hop ${ }^{1}$, Jørgen Berge ${ }^{3}$, Harald Steen ${ }^{1}$ \\ ${ }^{1}$ Norwegian Polar Institute, Fram Centre, 9296 Tromsø, Norway \\ ${ }^{2}$ University Centre in Svalbard, Box 156, 9171 Longyearbyen, Norway \\ ${ }^{3}$ Faculty of Biosciences, Fisheries and Economics, UiT-The Arctic University of Norway, 9037 Tromsø, Norway \\ ${ }^{4}$ Scottish Ocean Institute, University of St Andrews, St Andrews, Fife, KY16 8LB, United Kingdom \\ ${ }^{5}$ Department of Biology, Pomona College, Claremont, California 91711, USA \\ ${ }^{6}$ Department of Environmental Earth System Science, Stanford University, Stanford, California 94305, USA
}

\begin{abstract}
Oceanographic processes and bathymetric features that consistently aggregate prey are often thought to be the main cues used by planktivorous birds to detect suitable foraging habitat. In this study we aimed to establish the main factors determining the at-sea distribution of the little auk Alle alle, a very abundant seabird in the Arctic during the chick-rearing period. Multiyear data from vessel-based bird counts along the west coast of Spitsbergen were compared with hydro-acoustic prey estimates (top $30 \mathrm{~m}$ water layer), bathymetry, and sea surface temperature (SST) at 2 spatial scales: fine- $(3 \mathrm{~km})$ and meso-scale $(12 \mathrm{~km})$. Acoustic data for the top $10 \mathrm{~m}$ water layer was omitted due to excess noise. However, the amount of prey in the upper layer was assumed to be reflected by the prey in the deeper $(20$ to $30 \mathrm{~m}$ ) layer because of the unsynchronized diel vertical migration performed by zooplankton under midnight sun conditions. We found that the foraging distribution of little auks was mainly restricted to the continental shelf, presumably due to high availability of Arctic zooplankton there. Also, little auks preferred habitat characterized by low SST and flat sea-bottom. Such areas are likely to contain the preferred prey species of little auks, given that Arctic zooplankton distribution is linked to cold ocean temperatures. The number of little auks at sea increased with increasing abundance of macrozooplankton, but was not correlated with their preferred mesozooplankton prey. We conclude that physical features play an important role for the foraging habitat selection of little auks. Aggregations of macrozooplankton may be easier for the birds to detect than smaller-sized mesozooplankton and may be more important for adult little auks than previously thought.
\end{abstract}

KEY WORDS: Alle alle $\cdot$ Spatial distribution $\cdot$ Zooplankton $\cdot$ Bathymetry $\cdot$ Sea surface temperature $\cdot$ Foraging

Resale or republication not permitted without written consent of the publisher

\section{INTRODUCTION}

Seabirds feeding on plankton may be challenged to find sufficient amounts of food to cover their energetic needs due to the patchy distribution of their prey in the ocean (Hunt et al. 1998, Ladd et al. 2005, Blachowiak-Samolyk et al. 2006, Trudnowska et al. 2012). However, their ability to detect suitable foraging patches is enhanced by different oceanographic features and processes that aggregate prey in the upper part of the water column, such as upwelling due to interactions between currents and bathymetric gradients, tidal forcing and the continental shelf break (Hunt \& Schneider 1987, Hunt et al. 1999, Fauchald 2009). Planktivorous seabirds with energetically expensive modes of travel should particularly favour these predictable concentrations of prey to optimize foraging and to save energy (Stephens \& Krebs 1986, Hunt 1991).

Prey patches occur at various spatial scales, from fine-scale $(<10 \mathrm{~km})$ to meso- and large-scale (10s to 100s of km; Stephens \& Krebs 1986). While meso- 
and large-scale patches are commonly linked to oceanographic processes and features mentioned above, fine-scale patches are partly formed by prey congregating in dense swarms to avoid predation (Fauchald et al. 2000). Fine-scale aggregations are likely to change faster than meso- and large-scale patches, resulting in weaker spatial correlation between seabirds and prey at smaller scales (Russell et al. 1992). Also, when prey is superabundant, encounter rates with prey may be so high that it is energetically inefficient to travel to foraging sites with maximum prey density, leading to weak spatial correlation between predator and prey (e.g. Pianka 1986).

The small (ca. 150 to $160 \mathrm{~g}$ body mass), planktivorous little auk Alle alle is the most abundant seabird species breeding in the high Arctic (Stempniewicz 2001, Barrett et al. 2006). Little auks lay a single-egg clutch and the chick is frequently fed by both partners of a pair until the end of the chick-rearing period when only males are left to take care of the chick (Harding et al. 2004, Wojczulanis-Jakubas \& Jakubas 2012). Recently, little auks have been shown to use a bimodal foraging strategy with 1 long trip (LT) to distant foraging sites to self-feed, alternating with 3 to 5 short trips (ST) to near-colony waters to collect food for their chicks (Steen et al. 2007, WojczulanisJakubas et al. 2010, Brown et al. 2012, Welcker et al. 2012). Little auks feed mainly on Calanus copepods that are abundant in the surface waters $(<50 \mathrm{~m}$ depth) during the breeding period of little auk throughout its breeding range (Weslawski et al. 1999, Karnovsky et al. 2003, Kwasniewski et al. 2010). Prey other than Calanus, such as krill and amphipods, are thought to play a minor role as food for little auks during the reproductive season (Stempniewicz 2001). Calanus species differ in size and energy content, and species associated with cold Arctic water (e.g. C. glacialis and C. hyperboreus) contain up to $25 \%$ more lipids ( $\mathrm{mg}^{-1}$ dry weight) than their smaller, Atlantic water counterparts (e.g. C. finmarchicus) (Scott et al. 2000). Therefore, little auks are hypothesized to preferentially forage in cold water masses (Weslawski et al. 1999, Karnovsky et al. 2003, Jakubas et al. 2011). Little auks are wing-propelled divers (average and maximum diving depths $\sim 10 \mathrm{~m}$ and $\sim 35 \mathrm{~m}$, respectively; Falk et al. 2000, Harding et al. 2009, Karnovsky et al. 2011, Brown et al. 2012), with a wing anatomy that results in high energy costs during flight (Gabrielsen et al. 1991, Elliott et al. 2013). High flight costs together with a high chick feeding rate constrain the foraging range of little auks to max. $150 \mathrm{~km}$ (Jakubas et al. 2013).
We studied the at-sea distribution of foraging little auks at the west coast of Spitsbergen where some of the largest aggregations of breeding little auks are found (Isaksen 1995). The foraging area of little auks in this region is characterized by the occurrence of both Atlantic and Arctic water masses. The West Spitsbergen Current (WSC) transports Atlantic water (temperature $[T]>3^{\circ} \mathrm{C}$, salinity $>34.95 \mathrm{PSU}$ ) into the region along the steep continental shelf break from the Norwegian Sea and Arctic water $\left(T<0^{\circ} \mathrm{C}\right.$, salinity: 34.3 to $34.8 \mathrm{PSU}$ ) is carried to the area over the continental shelf by the South Cape Current from the north-western Barents Sea. These 2 water masses are separated by a front (Saloranta \& Svendsen 2001) that varies in strength and tends to break down during summer (Walkusz et al. 2009). Atlantic water is then able to cross the front and, mixed with Arctic shelf water, may enter the open fjords in west Spitsbergen (Hop et al. 2006, Cottier et al. 2007). As the different water masses contain different zooplankton communities, these water fluxes are thought to have a considerable impact on the quality of little auk foraging habitat (e.g. Kwasniewski et al. 2012).

Besides ocean temperature and associated prey, there are a suite of physical features that likely affect prey abundance and hence habitat use of little auks. The shelf break fronts with their constant water divergence and upwelling of nutrient-rich water are often thought to offer predictably high prey abundance for many seabird species, including little auks (Follestad 1990, Schneider 1991). However, these fronts may be of secondary importance compared to shelf waters that are often highly productive due to interactions between tidal currents, wind patterns and sea-bottom that break down the stratification and result in upwelling of deep-water nutrients (Sakshaug 2004). This is especially true in Spitsbergen where the highest zooplankton abundances are often observed in the shelf sea area (Daase \& Eiane 2007, BlachowiakSamolyk et al. 2008). In addition, the interplay of currents with small-scale sea-bottom gradients may lead to local upwelling and hence to predictable prey patches for little auks (Bakun 1996, Hunt 1997).

The aim of this study was to establish the main factors determining the at-sea distribution of foraging little auks during the breeding season. Over $4 \mathrm{yr}$, we counted the number of little auks along 157 transects off western Spitsbergen and simultaneously estimated prey abundance by means of hydro-acoustics. We hypothesized that (1) little auks would generally favour foraging sites with prevailing cold Arctic water due to their preference for lipid-rich prey associated with such water masses, (2) little auks would 
favour foraging sites with small-scale sea-bottom gradients that may concentrate prey in the upper part of the water column when interacting with currents, and (3) little auks would be more abundant on the shelf in contrast to off-shelf waters due to a likely higher amount of zooplankton on the shelf. In addition, we determined the spatial correlation between the occurrence of little auks and the abundance of their prey at 2 spatial scales: fine-scale $(3 \mathrm{~km})$ and meso-scale $(12 \mathrm{~km})$. We predicted a stronger relationship between predator and prey at the larger scale.

\section{MATERIALS AND METHODS}

\section{Study area and bird observations}

We carried out transect surveys with the research vessel RV 'Helmer Hanssen' along the shelf and offshelf waters west of Spitsbergen, Svalbard, during the chick rearing phase (second half of July; e.g. Stempniewicz 2001) over 4 yr: 13-18 July 2006, 25-26 July 2007, 16-22 July 2009 and 17-26 July 2010. The general survey area extended from approx. $2-16^{\circ} \mathrm{E}$ and from $77-79^{\circ} \mathrm{N}$ in all years, except in 2007 when only a smaller part of the area could be covered (Fig. 1). The actual cruise track and the location of transects varied to some extent among years, and observations were performed opportunistically. We regarded a transect as a continuous, straight line, with start and end points determined by the vessel changing direction, or slowing down/stopping, respectively. The number of surveyed transects varied from 21 to 70 during the study years, with mean transect lengths of 7.6 to $23.4 \mathrm{~km}$ (Table 1).

We counted little auks continuously from the vessel's bridge (eye height $15 \mathrm{~m}$ above sea level) within an arc of $300 \mathrm{~m}$ from the bow to $90^{\circ}$ abeam of the ship, while the vessel kept a constant speed of

Fig. 1. Study area with the main water currents (inset) during 2006 to 2007 and 2009 to 2010 at the west coast of Spitsbergen, Svalbard. The locations and sizes of some of the known little auk colonies (black dots), and zooplankton net-sampling stations during 2010 (coded unfilled octagons) are shown. The isobaths of $250 \mathrm{~m}$ and $750 \mathrm{~m}$ were used to separate shelf sea (coloured dots), shelf break (coloured triangles) and deep-sea zones (coloured squares) along the cruise paths

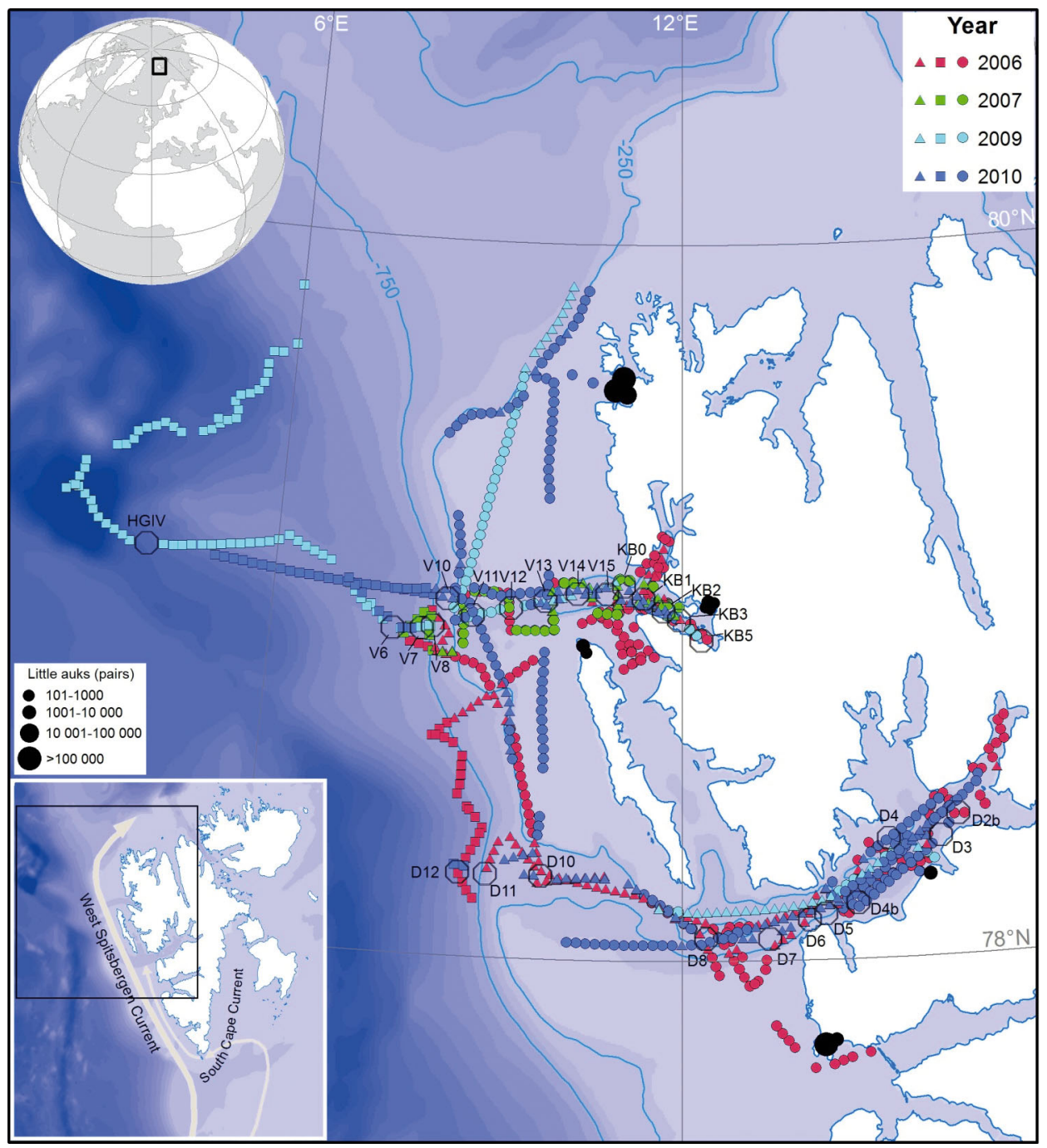


Table 1. Alle alle. Number of transects $(\mathrm{T})$ and bins (3 $\mathrm{km}$ and $12 \mathrm{~km}$ ), transect length (mean $\pm \mathrm{SE}$ ), and mean number of little auks (ind. \pm SE) observed per transect, $3 \mathrm{~km}$ and $12 \mathrm{~km}$ bins from 2006 to 2010

\begin{tabular}{|c|c|c|c|c|c|c|c|}
\hline Year & $\mathrm{T}$ & T length (km) & Ind. $\mathrm{T}^{-1}$ & $3 \mathrm{~km}$ & Ind. $3 \mathrm{~km}^{-1}$ & $12 \mathrm{~km}$ & Ind. $12 \mathrm{~km}^{-1}$ \\
\hline 2006 & 70 & $13.7 \pm 2.3$ & $39.0 \pm 7.4$ & 318 & $8.6 \pm 0.8$ & 53 & $6.0 \pm 1.0$ \\
\hline 2007 & 21 & $7.6 \pm 0.8$ & $64.4 \pm 12.5$ & 53 & $25.5 \pm 4.4$ & 5 & $19.0 \pm 9.0$ \\
\hline 2009 & 28 & $16.8 \pm 3.2$ & $15.4 \pm 4.9$ & 157 & $2.8 \pm 0.7$ & 26 & $2.0 \pm 1.0$ \\
\hline 2010 & 38 & $23.4 \pm 5.4$ & $145.4 \pm 32.3$ & 297 & $18.6 \pm 2.9$ & 58 & $12.0 \pm 3.0$ \\
\hline
\end{tabular}

ca. 9 knots $\left(17 \mathrm{~km} \mathrm{~h}^{-1}\right.$; Tasker et al. 1984). The constant daylight of the Arctic summer allowed us to count birds continuously throughout the day. Observations were discontinued whenever the vessel slowed down or stopped due to trawling and net casts, respectively. Only swimming little auks or birds emerging from water were recorded, as they probably were about to forage, or had just been foraging (Hunt et al. 1996). Binoculars $\left(10 \times 42,6.3^{\circ}\right)$ were used to confirm visual observations. Each observation was assigned a time and a spatial position from the vessel's global positioning system (GPS). As high waves can substantially limit the detectability of a small bird, such as the little auk, we estimated sea surface conditions (sea state) during each survey with a scale from 1 (calm, waves $\leq 0.1 \mathrm{~m}$ ) to 5 (rough, waves $\geq 4 \mathrm{~m}$ ) simultaneously with little auk counts.

\section{Hydro-acoustic estimates of prey availability}

In order to estimate abundance and spatial distribution of little auk prey, we used a downward facing, hull-mounted Simrad EK60 echo-sounder (beam angle $7^{\circ}$ ) operating at frequencies of 38 and $120 \mathrm{kHz}$ and a ping rate of 0.5 pings $\mathrm{s}^{-1}$ to gather backscatter information from the water column (surface to near seabed). We logged data simultaneously with little auk counts using Echolog 60 (SonarData), and these continuously recorded data included time and spatial position from the vessel's GPS. Ship engine noise and impacts with sea ice produced noise spikes and bubble occlusions in the acoustic record, but these were removed in post-processing.

We calibrated the echo-sounder at all frequencies just prior to the surveys, and conducted acoustic postprocessing using Echoview (SonarData). To remove stochastic ping-to-ping variation, we resampled calibration-corrected acoustic data at each frequency onto a 12 ping (horizontal) $\times 2 \mathrm{~m}$ (vertical) grid (as in Brierley et al. 1998). With this resampled data, we removed TVG (time varied gain) amplified noise as per Watkins \& Brierley (1996), and background noise using the signal-to-noise ratio (SNR) technique as per De Robertis \& Higginbottom (2007). We only considered data from the upper $30 \mathrm{~m}$ of the water column, which coincides with the diving depths of little auks (Falk et al. 2000, Harding et al. 2009, Karnovsky et al. 2011, Brown et al. 2012), but because of the draft of the ship's hull $(6 \mathrm{~m})$ and excess noise in the immediate vicinity of the ship and surface layer, the near field of 0 to $10 \mathrm{~m}(0$ to $10 \mathrm{~m}$ at $38 \mathrm{kHz}$ and 0 to $6.5 \mathrm{~m}$ at $120 \mathrm{kHz}$ ) was omitted. However, it is likely that prey abundance in the $10 \mathrm{~m}$ surface layer at any time of the day was reflected by the prey abundance in the deeper 10 to $30 \mathrm{~m}$ layer, as Calanus spp. have been shown to remain at depths $<50 \mathrm{~m}$ (BlachowiakSamolyk et al. 2006) and to perform unsynchronized diel vertical migration throughout the entire $24 \mathrm{~h}$ cycle (Cottier et al. 2006, Wallace et al. 2013) in the presence of midnight sun conditions.

To create systematic transect data from the continuous acoustic record and little auk counts, we binned data along each transect using a horizontal $3 \mathrm{~km}$ (along-track) $\times 300 \mathrm{~m}$ (cross-track) grid ( 10 min survey time) for counts and a $3 \mathrm{~km}$ (along-track) $\times 20 \mathrm{~m}$ (vertical) grid $(20 \mathrm{~m}=10$ to $30 \mathrm{~m}$ depth layer) for acoustics, which then formed the basis for all subsequent analyses. These grids were chosen to optimize the spatial and temporal correspondence between bird count and hydro-acoustic data and to avoid an excess of zero counts in the bird data (see 'Data analyses below). Also, the chosen grid sizes corresponded to previously observed sizes of zooplankton assemblages in the Svalbard area (Våge 2007, Trudnowska et al. 2012).

The acoustic grid was then used to calculate a 'Mean Volume Backscattering Strength' (MVBS = $10 \log _{10}\left[\right.$ mean $\left.\left(\mathrm{S}_{\mathrm{v}}\right)\right]$, where $\mathrm{S}_{\mathrm{v}}$ is the volume backscattering strength) along all transects within the surveyed area.

To classify the backscatter, we calculated $\triangle \mathrm{MVBS}$ (Madureira et al. 1993) using:

$\triangle \operatorname{MVBS}(\mathrm{dB})=$

MVBS (dB) $120 \mathrm{kHz}-$ MVBS (dB) $38 \mathrm{kHz}$ 
We defined mesozooplankton by a $\triangle$ MVBS of $>12 \mathrm{~dB}$ (size $<10 \mathrm{~mm}$ ), and this partition of the backscatter only included echoes from targets that are smaller than krill, including the copepods favoured as prey items by foraging little auks. Macrozooplankton/micronekton (including euphausiids) were defined by a $\triangle$ MVBS of 2 to $12 \mathrm{~dB}$ (size $>10 \mathrm{~mm}$ ), and nekton (including fishes and squid) by a $\triangle \mathrm{MVBS}$ of $<2 \mathrm{~dB}$. MVBS partitioning was based on the real length measurements of zooplankton collected during the 2009 and 2010 surveys with a WP-2 net (mouth opening $0.25 \mathrm{~m}^{2}$, mesh size $500 \mu \mathrm{m}$ ) from the top $50 \mathrm{~m}$ of the water column (Fig. 1). In total, 9 and 26 net-samples were taken during 2009 and 2010, respectively. The lengths measured were applicable to acoustic data collected during all survey years as the characteristic size-classes of e.g. macrozooplankton were rather consistent. Multi-frequency differentiation in this manner is now commonplace amongst studies using acoustic observations (Fernandes \& Stewart 2004). Even though nekton is usually not part of the little auk diet (Karnovsky et al. 2003, Fort et al. 2010 ), it may imply the presence of meso- and macrozooplankton and attract little auks due to higher detectability. We then carried out echo integration for differentiated zooplankton echoes using the $3 \mathrm{~km} \times$ $20 \mathrm{~m}$ grid. The integrated MVBS values $\left(\mathrm{S}_{\mathrm{v}}\right)$ were converted to $\mathrm{S}_{\mathrm{v}}\left(\mathrm{m}^{-1}\right.$; 'volume backscattering co-efficient' or sum of all discrete targets in the integrated volume), which were multiplied by $10^{9}$ to upscale from small volume $s_{v}$ values. These values were used as a proxy for zooplankton abundance. Upscaling was done to better detect relationships between birds and abundance estimates of zooplankton in the statistical analysis of the data. For detailed explanations of the relevant equations and definitions, see MacLennan et al. (2002).

To estimate the distribution of certain prey species in the study area, we also calculated the abundance (ind. $\mathrm{m}^{-3}$ ) of the 3 Calanus species (C. finmarchicus, C. glacialis and C. hyperboreus) and bigger prey items (i.e. krill and amphipods) from the total of 26 zooplankton net-samples collected during 2010.

\section{Environmental data}

Bathymetric data included bottom depth $(\mathrm{m})$ and bottom gradient $\left({ }^{\circ}\right)$, and were obtained from the International Bathymetric Chart of the Arctic Ocean at the horizontal resolution of $500 \times 500 \mathrm{~m}$ (www. ngdc.noaa.gov/mgg/bathymetry/arctic/arctic.html). We then estimated the mean bottom depth at the hor- izontal resolution of $3 \times 3 \mathrm{~km}$ along the cruise routes, and computed the mean bottom gradient at the same resolution as the mean difference between bottom depth in a given $3 \times 3 \mathrm{~km}$ bin and its adjacent $3 \times$ $3 \mathrm{~km}$ bins under a Geographic Information System (Esri ArcGIS). We distinguished shelf and off-shelf zones based on composition of zooplankton community; isobaths of $200 \mathrm{~m}, 242 \mathrm{~m}$ and $300 \mathrm{~m}$ have been previously shown to divide Arctic and Atlantic zooplankton communities over shelf and off-shelf zones, respectively (Karnovsky et al. 2003, 2010, Kwasniewski et al. 2012) and in this study we used $250 \mathrm{~m}$ as a compromise (Fig. 1). To further separate off-shelf zones into shelf-break and deep-sea zones, we used an isobath of $750 \mathrm{~m}$ (Fig. 1; Blachowiak-Samolyk et al. 2007). Consequently, we divided bird counts into these 3 categories (factor sea zone).

In our study area, summer sea surface temperature $\left(\mathrm{SST}_{1}{ }^{\circ} \mathrm{C}\right)$ has been shown to be strongly linked to species composition of local zooplankton communities, with large lipid-rich copepods inhabiting cold water (Karnovsky et al. 2010). Thus, we used SST to characterize oceanographic conditions and the quality of little auk foraging habitat. Over the study period, Level-3 $8 \mathrm{~d}$ composites of SST were acquired at $4.6 \times$ $4.6 \mathrm{~km}$ horizontal resolution from the Moderate Resolution Imaging Spectroradiometer (MODIS/aqua; http://oceancolor.gsfc.nasa.gov/). This resolution was the highest available to spatially fit hydro-acoustic and bird count data. We projected these SST images onto an equal-area grid using the NASA software SeaDAS. Both bathymetric and SST data were assigned to the binned acoustic and count data based on the closest spatiotemporal correspondence.

\section{Data analyses}

We analysed our data at 2 spatial scales: fine$(3 \mathrm{~km})$ and meso-scale $(12 \mathrm{~km})$. For the meso-scale, we averaged acoustic, physical and little auk count data over 4 subsequent $3 \mathrm{~km}$ bins (as $3 \mathrm{~km}$ scale was our base scale). In total, we had 825 and 142 of $3 \mathrm{~km}$ and $12 \mathrm{~km}$ bins, respectively (Table 1 ).

We used sea state to gauge observation conditions during the bird surveys. Sea state was constantly low and varied between 1 and 2 (wave range 0.0 to $0.5 \mathrm{~m}$ ) during the surveys in 2007, 2009 and 2010, indicating generally good conditions for observers during those years. Sea state was somewhat more variable in 2006. We used a generalized linear model (GLM) with negative binomial distribution and log-link function to determine the effect of sea state on bird detectability 
Table 2. Mean and variance structure, and the estimated $\triangle$ AIC (Akaike's Information Criterion) and dispersion parameter of the candidate models used for the little auk count data at the fine $(3 \mathrm{~km})$ and meso $(12 \mathrm{~km}) \mathrm{spatial}$ scales. $\mu_{i}=$ mean of the positive count data for observation $i, \mu_{i j}=$ mean of the positive count data for observation $i$ within transect $j$, $\pi_{i}=$ probability that zero is a false zero for observation $i, k=$ unknown parameter to be estimated by the software (R), and $\alpha=1 / k$. The best model is shown in bold

\begin{tabular}{|c|c|c|c|c|c|c|}
\hline \multirow[t]{2}{*}{ Model } & \multirow[t]{2}{*}{ Mean } & \multirow[t]{2}{*}{ Variance } & \multicolumn{2}{|c|}{$\Delta \mathrm{AIC}$} & \multicolumn{2}{|c|}{ Dispersion parameter } \\
\hline & & & $3 \mathrm{~km}$ & $12 \mathrm{~km}$ & $3 \mathrm{~km}$ & $12 \mathrm{~km}$ \\
\hline Poisson GLM & $\mu_{i}$ & $\mu_{i}$ & 21334.8 & 1338.3 & 63.9 & 24.9 \\
\hline NB GLM & $\mu_{i}$ & $\mu_{i}+\alpha \times \mu_{i}^{2}$ & 183.6 & 10.6 & 1.6 & 1.8 \\
\hline ZIP GLM & $\mu_{i} \times\left(1-\pi_{i}\right)$ & $\left(1-\pi_{i}\right) \times\left(\mu_{i}+\pi_{i} \times \mu_{i}^{2}\right)$ & 16248.9 & 1219.7 & 11.6 & 16.6 \\
\hline ZINB GLM & $\mu_{i} \times\left(1-\pi_{i}\right)$ & $\left(1-\pi_{i}\right) \times \mu_{i} \times\left(1+\pi_{i} \times \mu_{i}+\mu_{i} / k\right)$ & 156.1 & 12.6 & 1.6 & 1.8 \\
\hline Poisson GLMM & $\mu_{i j}$ & $\mu_{i j}$ & 5234.3 & 33.8 & 16.0 & 5.2 \\
\hline NB GLMM & $\mu_{i j}$ & $\mu_{i j}+\alpha \times \mu_{i j}^{2}$ & 0.0 & $\mathbf{0 . 0}$ & 0.9 & 1.0 \\
\hline
\end{tabular}

in 2006. This model suggested that detectability of little auks within the $300 \mathrm{~m}$ observation range was not significantly reduced with increasing sea state (for all parameter estimates: $Z$ (effect size): -0.76 to 0.95 , p: 0.448 to 0.920 ). This was likely the case because observation conditions were generally favourable in 2006 and increased sea state occurred only during relatively short time periods. We therefore excluded 'sea state' from further analyses.

We initially considered 7 potential explanatory variables to explain the at-sea distribution of little auks: acoustic data on nekton, meso- and macrozooplankton, bottom gradient, sea zone, SST and survey year. Assessment of the data (both explanatory and response variables) by Cleveland dot-plots indicated that the data contained no outliers. To gauge potential collinearity between explanatory variables, we used variance inflation factors (VIFs; Zuur et al. 2012). In contrast to traditional pair-plots that capture only 2-way relationships, VIFs are able to detect multidimensional collinearity between variables. VIF values $<3$ indicate that collinearity is negligible (Zuur et al. 2012). For our data, VIFs showed strong collinearity between nekton and macrozooplankton (VIFs >3). We removed nekton from the data set because nekton as such is usually not part of the little auk's diet.

We applied standard GLMs with both Poisson and negative binomial (NB) distributions and log-link functions, and we also considered models that account for potential zero inflation (see Appendix 1): zero-inflated Poisson GLM (ZIP GLM) and zeroinflated NB GLM (ZINB GLM; Table 2). NB GLM is similar to that of a Poisson GLM except for the extra quadratic term in the variance, which allows for extra over-dispersion in counts (Table 2). In ZIP and ZINB, data are divided into 2 imaginary groups: the first group contains only zeros (false zeros), and the second group is made up of the count data (true zeros and values $>$ zero). The probability of a false zero versus count data is assumed to be binomially distributed (logit-link), and count data are assumed to follow a Poisson or NB distribution (log-link). Also, we considered that little auk observations within transects may be more similar than between transects. Therefore, in addition to the 4 models already mentioned, we applied generalized linear mixed models with Poisson (Poisson GLMM) and negative binomial distributions (NB GLMM; Table 2), with transect as a random effect. We ran all 6 models both with and without 2-way interactions between survey year and other explanatory variables.

Among these candidate models, we chose the final model (NB GLMM) at both $3 \mathrm{~km}$ and $12 \mathrm{~km}$ spatial scales based on the lowest Akaike's Information Criterion (AIC; Akaike 1973). To assure that the final model adequately fitted the data, we also considered the dispersion parameter for all models. A dispersion parameter $>1$ is considered as a sign of overdispersion and thus lack of fit (Long 1997). We validated the final models by extracting the Pearson residuals and plotting them against (1) the fitted values, (2) each explanatory variable in the model, and (3) each explanatory variable not in the model (i.e. variable excluded due to collinearity). Instead of viewing plotted graphs in options 2 and 3, we applied a generalized additive model (GAM), with Pearson residuals as a response variable and the continuous explanatory variables (nekton, meso- and macrozooplankton, bottom gradient and SST) as smoothers. In the case of categorical explanatory variables (sea zone and survey year), we used GAM without adding a smoother effect into the model. A significant smoother or significant categorical variable in GAM would indicate model misspecification.

Spatial autocorrelation is a typical phenomenon occurring in species distributional data, and it vio- 
lates the assumption of sample-independence in most of the statistical approaches. This can lead to Type I errors, i.e. false significant results (Legendre et al. 2002). Therefore, we used sample variograms to explore spatial autocorrelation among the Pearson residuals of the final models (see Appendix 1; Zuur et al. 2012).

We performed all analyses in R 2.15.0 (R Development Core Team 2012), with significance set to $\mathrm{p}<$ 0.05. Statistical packages used in $\mathrm{R}$ were 'lme4', 'pscl', 'MASS' and 'glmmADMB'.

\section{RESULTS}

All the surveyed transects were located within the foraging range $(\sim 150 \mathrm{~km})$ of a little auk colony (Fig. 1). The average number of little auks varied from 15.4 to 145.4 per transect, from 2.8 to 25.5 per $3 \mathrm{~km}$ bin and from 2.0 to 19.0 per $12 \mathrm{~km}$ bin (Table 1 ). The sea-bottom gradient ranged from $0^{\circ}$ (flat sea floor) to $18^{\circ}$ (steepest gradient) in the study area. SST varied from 0 to $7^{\circ} \mathrm{C}$ during the study years (Fig. 2). Highest SST $\left(>4^{\circ} \mathrm{C}\right)$ was observed along the
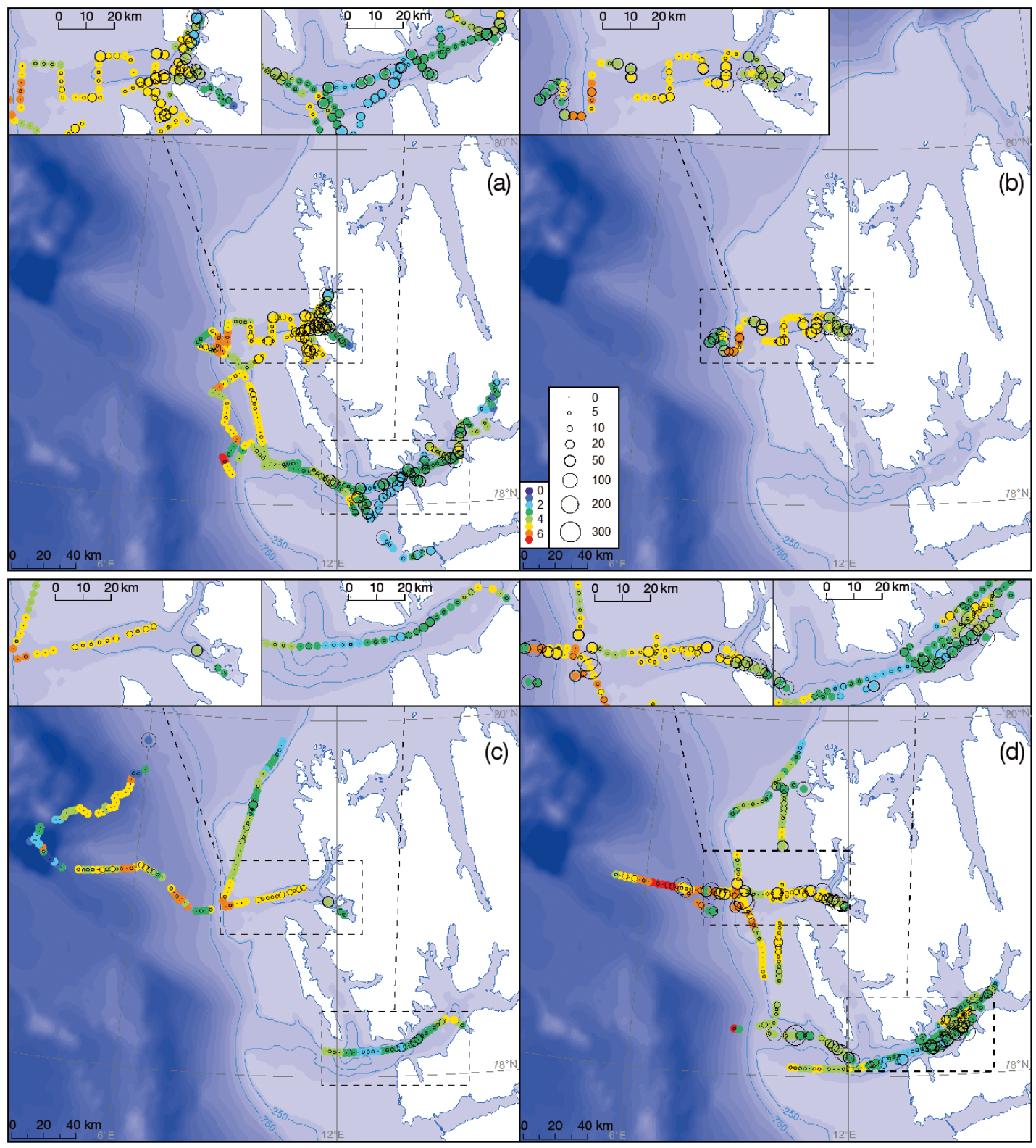

Fig. 2. Level-3 $8 \mathrm{~d}$ composites of sea-surface temperature $\left({ }^{\circ} \mathrm{C}\right.$, coloured dots) at $4.6 \times 4.6 \mathrm{~km}$ horizontal resolution, and number of little auks (black circles) at $3 \mathrm{~km}$ (along-track) × $300 \mathrm{~m}$ (cross-track) resolution in the study area during (a) 2006, (b) 2007,

(c) 2009, and (d) 2010 

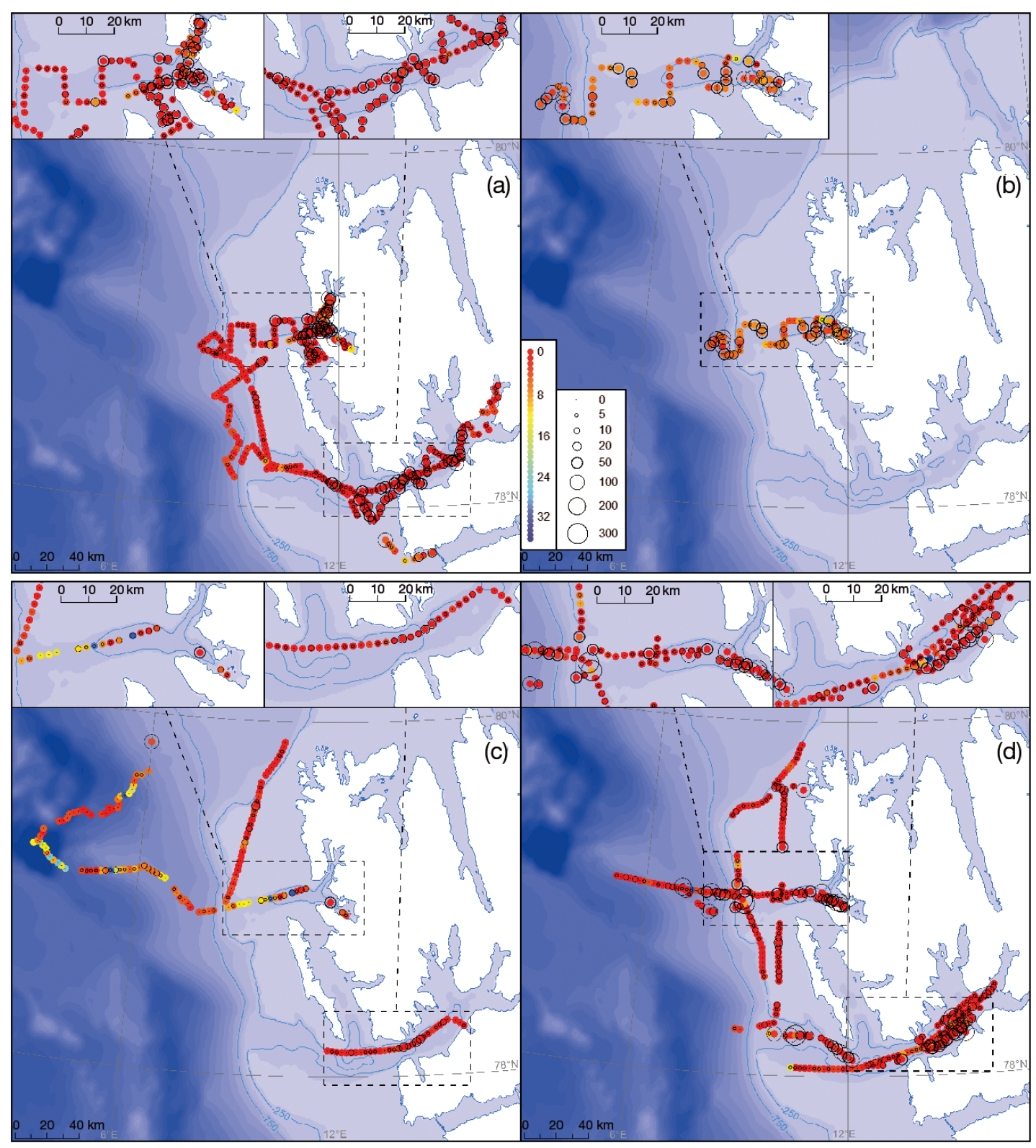

Fig. 3. Abundance estimates of mesozooplankton $\left(\mathrm{s}_{\mathrm{v}}\left[\mathrm{m}^{-1} \times 10^{9}\right]\right.$, coloured dots) at $3 \mathrm{~km}$ (along-track) $\times 20 \mathrm{~m}($ vertical) resolution (where $20 \mathrm{~m}=10$ to $30 \mathrm{~m}$ depth layer), and number of little auks (black circles) at $3 \mathrm{~km}$ (along-track) $\times 300 \mathrm{~m}$ (cross-track) resolution in the study area during (a) 2006, (b) 2007, (c) 2009, and (d) 2010

shelf break/deep sea, and over the shelf outside the fjords. Inside the fjords, SST was generally lower $\left(\leq 4^{\circ} \mathrm{C}\right)$, although higher SSTs were also observed (Fig. 2). The abundance estimates of mesozooplankton varied between 0 and $37 \mathrm{~s}_{\mathrm{v}}\left(\mathrm{m}^{-1} \times 10^{9}\right)$ during the study years, and were highest over the deep sea zone (Fig. 3). The abundance estimates of macrozooplankton were more variable throughout the study area (range: 0 to $88 \mathrm{~s}_{\mathrm{v}}\left[\mathrm{m}^{-1} \times 10^{9}\right]$ ), and were highest over the shelf break and deep sea zones (Fig. 4).
Copepods Calanus glacialis and C. hyperboreus were generally more abundant than $C$. finmarchicus over the shelf sea zone (Fig. 5a). Towards the shelf break and deep sea zones, the abundance of $C$. finmarchicus exceeded that of the 2 other Calanus species (Fig. 5a). The abundance of macrozooplankton (krill and amphipods) was also higher towards the shelf break and deep sea zones (Fig. 5b). Nearly all sampled stations had a relatively high abundance $\left(\geq 400\right.$ ind. $\mathrm{m}^{-3}$ ) of Calanus, whereas macrozooplankton was missing at some of the stations (Fig. 5). 

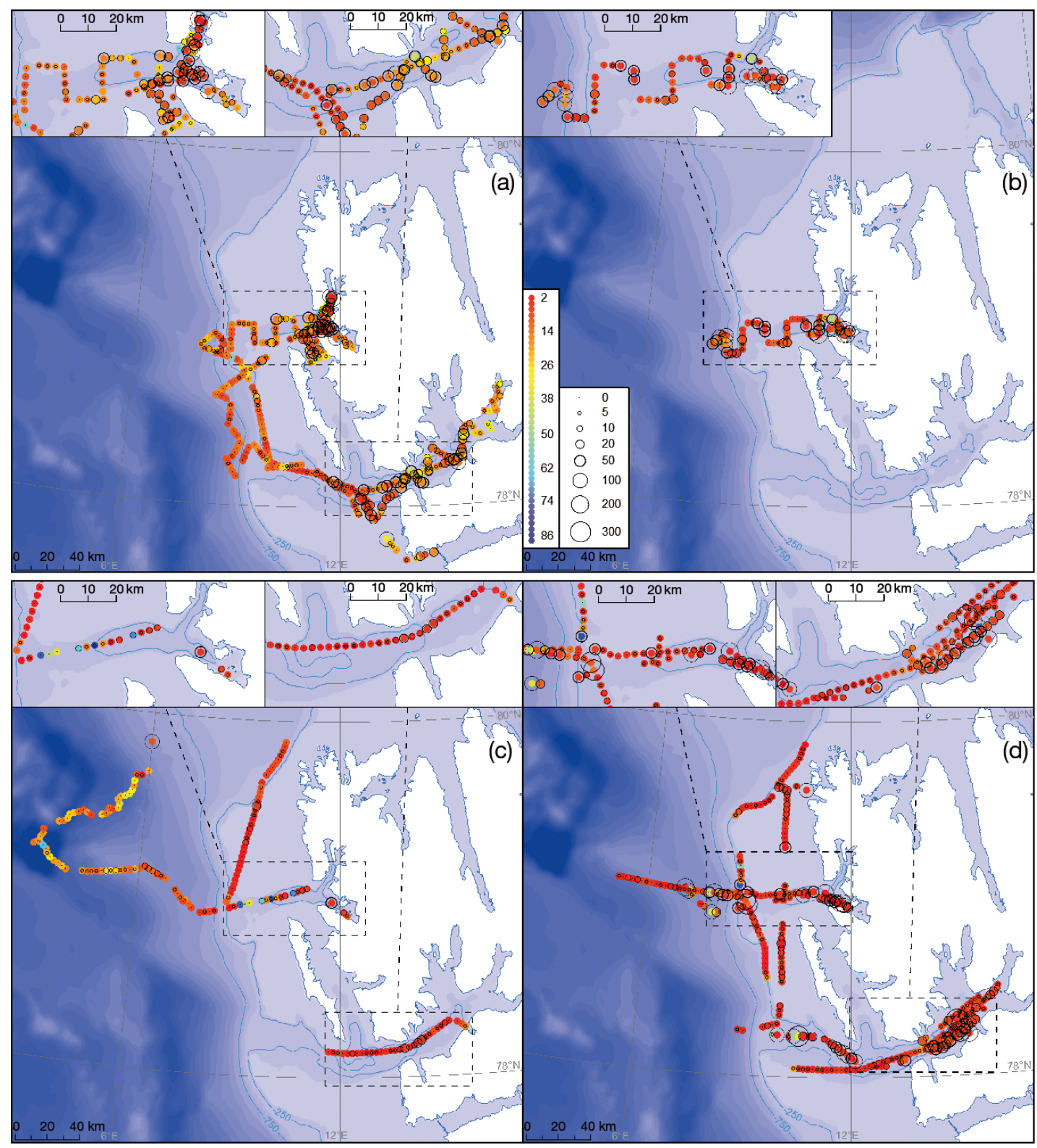

Fig. 4. Abundance estimates of macrozooplankton $\left(\mathrm{s}_{\mathrm{v}}\left[\mathrm{m}^{-1} \times 10^{9}\right]\right.$, coloured dots) at $3 \mathrm{~km}$ (along-track) $\times 20 \mathrm{~m}(\mathrm{vertical})$ resolution (where $20 \mathrm{~m}=10$ to $30 \mathrm{~m}$ depth layer), and number of little auks (black circles) at $3 \mathrm{~km}$ (along-track) $\times 300 \mathrm{~m}$ (cross-track) resolution in the study area during (a) 2006, (b) 2007, (c) 2009, and (d) 2010

The models (Table 2) showed less fit to the data when they were run with 2-way interactions between survey year and other explanatory variables compared to models without these interactions ( $\triangle$ AIC $\sim 4$, not shown in table). Amongst the additive models, the final model best describing the data at both $3 \mathrm{~km}$ and $12 \mathrm{~km}$ spatial scales was the NB GLMM, with transect as a random effect (Table 2). Dispersion parameter of this final model was $\sim 1$ at both spatial scales, indicating a good fit of the model to the data. All other models led to substantial over-dispersion
(Table 2). Validating the NB GLMMs did not reveal significant smoothers or categorical explanatory variables that were included in or excluded from the model (GAM: $p$ > 0.05). We detected no patterns in the Pearson residuals when we plotted them against the fitted values (see Appendix 1; Fig. A1a,b). Also, the sample variograms applied to the Pearson residuals did not indicate spatial autocorrelation at either of the spatial scales, $3 \mathrm{~km}$ and $12 \mathrm{~km}$ (see Appendix 1; Fig. A1c,d). Thus, we concluded that the NB GLMMs were indeed most appropriate to model our data. 


\section{Habitat selection}

At the $3 \mathrm{~km}$ spatial scale, the at-sea distribution of little auks was dependent on sea-bottom gradient, sea zone and SST (Table 3). Since 2-way interaction models fitted the data poorly, survey year only had an effect on how many little auks were observed at sea (Table 3 ), but not how other explanatory variables influenced the at-sea distribution (i.e. their influence was same regardless of the study year). The at-sea distribution of little auks was not influenced by the abundance estimates of meso- and macrozooplankton (Table 3). The number of little auks at sea increased with decreasing gradient of the sea-bottom (Fig. 6a) and decreasing SST (Fig. 6d), and was generally higher on the shelf sea zone compared to over the shelf break and deep sea zones (Fig. 6b). The number of little auks observed was higher in 2007 and 2010 than in 2006 and 2009 (Table 3).

Generally, results for the $12 \mathrm{~km}$ spatial scale resembled the results for the finer scale, although the relationship with SST was slightly weaker (Table 3, Fig. 6c,e). However, there was a strong, positive correlation between the at-sea

Table 3. The final model with respective explanatory variables used in the data analysis: sea-bottom gradient $\left({ }^{\circ}\right)$, sea zone (shelf sea/shelf break/deep sea), sea surface temperature $\left(\mathrm{SST}_{1}^{\circ} \mathrm{C}\right)$, macro- and mesozooplankton (macro and meso, respectively, $\mathrm{s}_{\mathrm{v}}$ $\left[\mathrm{m}^{-1} \times 10^{9}\right]$ ), and study year. Model results show Z-scores (i.e. effect sizes) and p-values for each variable at the fine $(3 \mathrm{~km})$ and meso $(12 \mathrm{~km})$ spatial scales. Deep sea zone and survey year 2006 are the reference levels (=Intercept) to which other sea zones and survey years are compared. ${ }^{*} \mathrm{p} \leq 0.05,{ }^{* *} \mathrm{p} \leq 0.01,{ }^{* * *} \mathrm{p}<0.001$

\begin{tabular}{|c|c|c|c|c|}
\hline \multirow{2}{*}{$\begin{array}{l}\text { Explanatory } \\
\text { variables }\end{array}$} & \multicolumn{2}{|c|}{$-Z=$} & \multirow[b]{2}{*}{$3 \mathrm{~km}$} & \multirow{2}{*}{$\overline{12 \mathrm{~km}}$} \\
\hline & $3 \mathrm{~km}$ & $12 \mathrm{~km}$ & & \\
\hline Intercept & 4.76 & 1.52 & $<0.001^{* * *}$ & 0.128 \\
\hline Sea-bottom gradient & -2.83 & -0.79 & $0.005^{* *}$ & 0.430 \\
\hline Shelf sea & 2.16 & 2.25 & $0.031^{*}$ & $0.025^{*}$ \\
\hline Shelf break & 0.68 & 1.29 & 0.495 & 0.196 \\
\hline SST & -2.74 & -2.38 & $0.006^{* *}$ & $0.017^{*}$ \\
\hline Macro & 1.71 & 3.79 & 0.088 & $<0.001^{* * *}$ \\
\hline Meso & -0.53 & -1.22 & 0.597 & 0.22 \\
\hline 2007 & 3.76 & 3.21 & $<0.001^{* * *}$ & $0.001^{* *}$ \\
\hline 2009 & -3.38 & -0.36 & $0.001^{* * *}$ & 0.718 \\
\hline 2010 & 3.11 & 3.18 & $0.002^{* *}$ & $0.001^{* *}$ \\
\hline
\end{tabular}
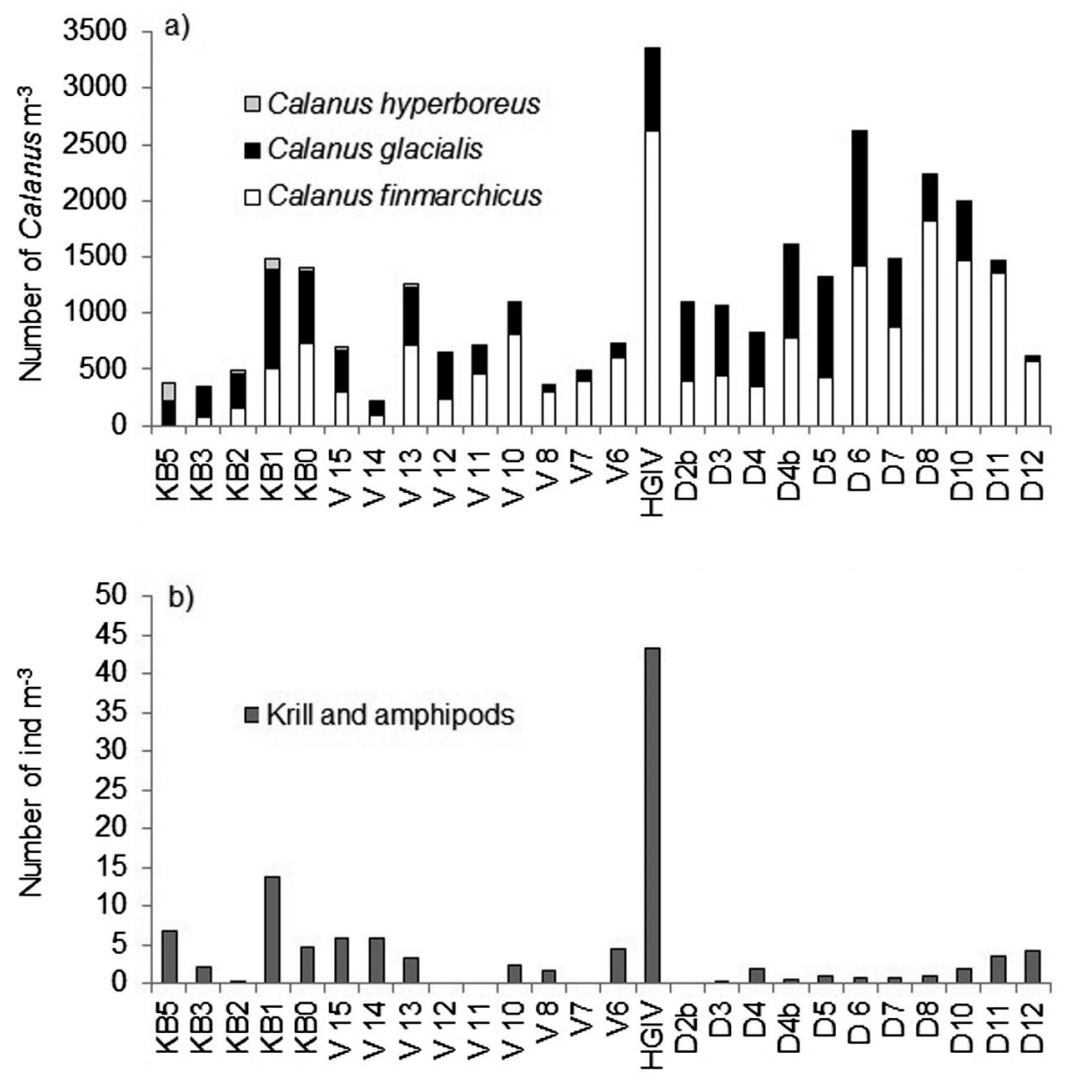

Sampling station

Fig. 5. Abundance (ind. $\mathrm{m}^{-3}$ ) of (a) Calanus finmarchicus, C. glacialis and C. hyperboreus, and (b) krill and amphipods in the zooplankton net-samples during 2010

distribution of little auks and macrozooplankton (Table 3, Fig. 6f), while no effect was detected between little auks and sea-bottom gradient (Table 3).

\section{DISCUSSION}

Our study aimed to determine the patterns and possible causes of the at-sea foraging distribution of little auks at the west coast of Spitsbergen. First, we predicted that the number of little auks would be negatively related to SST and positively related to small-scale gradients of the seabottom (i.e. local upwelling). While the first expectation was supported by our data, the latter was not. On the contrary, we found a negative correlation between the number of birds and the sea-bottom gradient at the fine spatial scale, suggesting that little auks more frequently use areas without pronounced sea-bottom features. Interactions between sea-bottom gradients and 

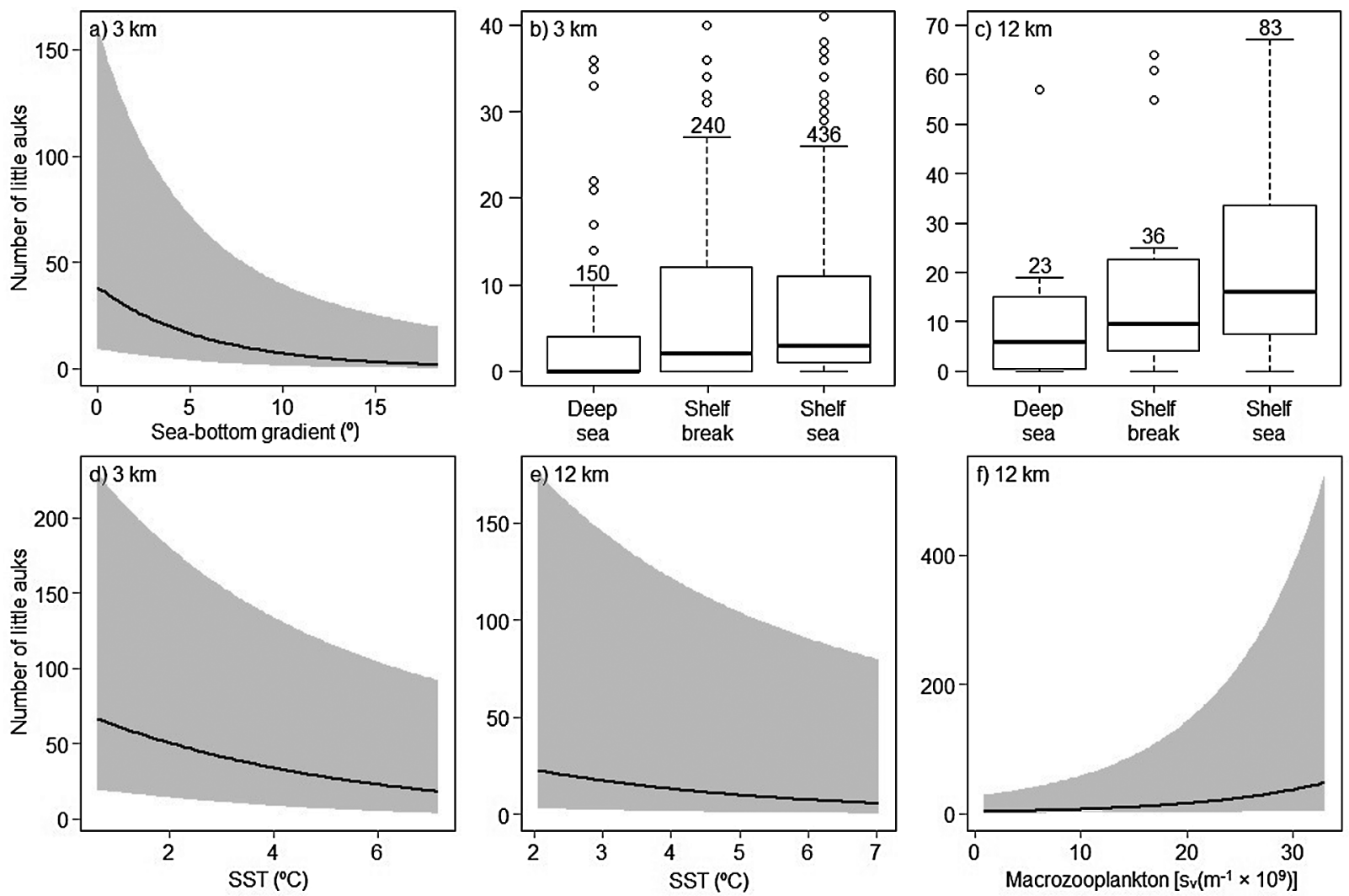

Fig. 6. Alle alle. Mean number of little auks in relation to (a) sea-bottom gradient $\left({ }^{\circ}\right),(\mathrm{b}, \mathrm{c})$ sea zone, $(\mathrm{d}, \mathrm{e})$ sea-surface temperature $\left(\mathrm{SST}^{\circ} \mathrm{C}\right)$, and (f) macrozooplankton abundance $\left[\mathrm{s}_{\mathrm{v}}\left(\mathrm{m}^{-1} \times 10^{9}\right)\right]$. Grey areas in plots (a) and (d-f) represent $95 \%$ confidence intervals, and spatial scale is indicated within each plot. Sample size (number of $3 \mathrm{~km}$ and $12 \mathrm{~km}$ bins) is given for each sea zone in plots (b) and (c); outliers are represented by circles

currents often result in upwelling, and abundant and predictable prey for a range of marine predators (Hunt 1991, Fauchald 2009) and other seabird studies have shown that regions with strong water divergence and thus enhanced biomass attract birds (e.g. Hunt et al. 1996, Ladd et al. 2005). Our result may partly be explained by changes in SST and the preference of little auks for cold Arctic water with lipid-rich prey. Interactions between currents and sea-bottom gradients may enhance upwelling of warm and dense Atlantic water from below cold and lighter Arctic water (Svendsen et al. 2002, Cottier et al. 2005, Ingvaldsen \& Loeng 2009), and hence may make these areas less suitable for little auks. Also, a recent study has shown that little auks aggregate in areas where prey are clearly visible (Stempniewicz et al. 2013). A pronounced sea-bottom gradient and resultant water divergence may produce turbulent water with poor visibility (Henkel 2006) and consequently may not attract foraging little auks. Several previous studies have hypothesized a negative correlation between the number of foraging little auks and SST (e.g. Karnovsky et al. 2003, 2010, Stempniewicz et al. 2007, Joiris \& Falck
2011). Our study confirmed that little auks are more common at low SST, presumably because of higher lipid content of their prey in cold Arctic water (Scott et al. 2000). Little auks likely select against species with less lipid content often found in warm Atlantic water, and one way to do that may be to seek out the pockets of cold water in the foraging area.

Further, we predicted that little auks would be more abundant in shelf waters than at the shelf break or deep sea zones, and this prediction was supported by our data at both the $3 \mathrm{~km}$ and $12 \mathrm{~km}$ scales. Shelf waters are generally very rich in zooplankton (e.g. Blachowiak-Samolyk et al. 2008), but our data showed that zooplankton was more abundant in offshelf waters. Why did not we see most little auks in off-shelf waters? One likely reason is that the prferred energy-rich Calanus glacialis is especially abundant in shelf waters, while less-preferred C. finmarchicus is more abundant off-shelf in our study area (Daase et al. 2007, Blachowiak-Samolyk et al. 2008, Søreide et al. 2008). Also, our net-samples collected during 2010 showed the similar distributional pattern of these 2 species. Distributions of Calanus 
align with different water masses in the west Spitsbergen region: shelf waters are dominated by Arctic water masses while Atlantic water masses dominate more off-shelf (Saloranta \& Svendsen 2001). However, despite the lower abundance of $C$. glacialis in off-shelf waters, they also seem to be popular foraging habitats due to a number of little auks observed there. These little auk occurrences could reflect for example higher abundance of macrozooplankton towards the shelf break and deep sea zones, as shown by our zooplankton data. Furthermore, little auks may forage over deep sea zones during their long self-feeding trips when they generally exploit distant foraging grounds, as has been previously shown in our study area (e.g. Brown et al. 2012).

Spatial correspondence between foraging seabirds and their prey is variable and dependent on the spatial scale (Piatt 1990, Hunt et al. 1999, Mehlum et al. 1999). Whilst some studies report strong positive correlations between seabirds and prey (e.g. Hunt et al. 1992, Mehlum et al. 1996, Pakhomov \& McQuaid 1996), others find only weak spatial relationships (e.g. Russell et al. 1992, Swartzman \& Hunt 2000). Also, many suggest that the aggregative response of seabirds to prey is stronger at larger spatial scales (Schneider \& Piatt 1986, Piatt 1990). In our study, little auks were positively correlated with macrozooplankton at the $12 \mathrm{~km}$ scale but not at the $3 \mathrm{~km}$ scale. This suggests that little auks may not be able to track fine-scale prey aggregations that are likely to change quickly (Russell et al. 1992), or may not need to if prey is sufficiently abundant.

However, we did not find a relationship between the at-sea distribution of little auks and mesozooplankton at 10 to $30 \mathrm{~m}$ depth, which we assume is also a representative of mesozooplankton abundance in the $10 \mathrm{~m}$ surface layer (see Cottier et al. 2006, Wallace et al. 2013) where little auks primarily forage (e.g. Karnovsky et al. 2011). Mesozooplankton is considered to be the main prey of little auks during the breeding season (Stempniewicz 2001, Karnovsky et al. 2003, Kwasniewski et al. 2010) and constitutes up to $95 \%$ of the food delivered to chicks (Jakubas et al. 2011). One plausible explanation for why little auks are associated with macro- but not with mesozooplankton is that the latter was more homogenously distributed in our study area. Relatively invariable yet sufficient prey availability across the foraging grounds may reduce the need of little auks to search aggregations of highest prey density (e.g. Pianka 1986, Fauchald 2009). The lack of spatial correspondence between little auks and their prey was also shown by Fauchald et al. (2011) in the North Sea.
Therefore, we speculate that instead of locating prey patches per se, little auks use other environmental factors (such as SST) to locate foraging areas likely offering the best quality prey (e.g. Calanus glacialis). Furthermore, macrozooplankton may be more easily detected by little auks than mesozooplankton due to its bigger size and it may also indicate a co-occurrence of mesozooplankton (e.g. Berge et al. 2012). However, macrozooplankton is also preyed upon by little auks (e.g. Stempniewicz 2001, Karnovsky et al. 2003, 2010). Studies of the little auk diet during the chick-rearing period are usually restricted to the food brought back by the parent birds for their chicks (e.g. Harding et al. 2008, Karnovsky et al. 2008, but see Fort et al. 2010). Whether the high proportion of Calanus copepods found in these samples reflects adult diet remains largely unknown. It has been shown that higher trophic level organisms (e.g. krill and amphipods) contribute more to the adult diet during autumn and winter months (Fort et al. 2010, Rosing-Asvid et al. 2013). However, due to the strong spatial correlation between little auks and macrozooplankton shown in our study, we propose that adult little auks prey on macrozooplankton to a larger extent in summer than previously assumed.

In summary, the at-sea distribution of little auks during the breeding season is mainly limited to the continental shelf. Within this range, oceanographic features and processes are seemingly important with the foraging habitat of little auks being characterized by cold water temperatures and flat sea-bottom. In addition, meso-scale processes may play a larger role in determining the at-sea distribution of little auks as indicated by stronger spatial correlation with prey at this scale. It remains to be tested whether larger scale $(100 \mathrm{~s}$ of $\mathrm{km})$ at-sea distribution of this species is determined by the same physical factors as shown in this study.

Acknowledgements. The study was funded by the Norwegian Research Council through project no. PNRF-234-AI1/07 (ALKEKONGE) and 165112/S30 (MariClim), and the Norwegian Polar Institute. All fieldwork was conducted under permits of the Governor of Svalbard. We thank all hard-working field assistants, ArcGIS manoeuvres and proof-readers: Anika Beiersdorf, Bernt Bye, Fredrik Broms, Anders Mæland, Thomas Nielsen, Nina Seifert, Mikko Vihtakari and Daniel Vogedes.

\section{LITERATURE CITED}

Akaike H (1973) Information theory and an extension of the maximum likelihood principle. In: Petrov BN, Csaki F (eds) Second international symposium on information theory. Akademiai Kiado, Budapest, p 267-281 
Bakun A (1996) Patterns in the ocean: ocean processes and marine population dynamics. California Sea Grant College System, National Oceanic and Atmospheric Administration (NOAA), La Jolla, CA

Barrett RT, Chapdelaine G, Anker-Nilssen T, Mosbech A, Montevecchi WA, Reid JB, Veit RR (2006) Seabird numbers and prey consumption in the North Atlantic. ICES J Mar Sci 63:1145-1158

Berge J, Gabrielsen TM, Moline M, Renaud PE (2012) Evolution of the Arctic Calanus complex: an Arctic marine avocado. J Plankton Res 34:191-195

> Blachowiak-Samolyk K, Kwasniewski S, Richardson K, Dmoch K and others (2006) Arctic zooplankton do not perform diel vertical migration (DVM) during periods of midnight sun. Mar Ecol Prog Ser 308:101-116

Blachowiak-Samolyk K, Kwasniewski S, Dmoch K, Hop H, Falk-Petersen S (2007) Trophic structure of zooplankton in the Fram Strait in spring and autumn 2003. Deep-Sea Res II 54:2716-2728

Blachowiak-Samolyk K, Søreide JE, Kwasniewski S, Sundfjord A, Hop H, Falk-Petersen S, Hegseth EN (2008) Hydrodynamic control of mesozooplankton abundance and biomass in northern Svalbard waters $\left(79.81^{\circ} \mathrm{N}\right)$. Deep-Sea Res II 55:2210-2224

Brierley AS, Brandon MA, Watkins JL (1998) An assessment of the utility of an acoustic doppler current profiler for biomass estimation. Deep-Sea Res I 45:1555-1573

> Brown ZW, Welcker J, Harding AMA, Walkusz W, Karnovsky NJ (2012) Divergent diving behaviour during short and long trips of a bimodal forager, the little auk Alle alle. J Avian Biol 43:215-226

Cottier F, Tverberg V, Inall M, Svendsen H, Nilsen F, Griffiths C (2005) Water mass modification in an Arctic fjord through cross-shelf exchange: the seasonal hydrography of Kongsfjorden, Svalbard. J Geophys Res 110:C12005, doi:10.1029/2004JC002757

Cottier FR, Tarling GA, Wold A, Falk-Petersen S (2006) Unsynchronized and synchronized vertical migration of zooplankton in a high Arctic fjord. Limnol Oceanogr 51: 2586-2599

> Cottier FR, Nilsen F, Inall ME, Gerland S, Tverberg V, Svendsen H (2007) Wintertime warming of an Arctic shelf in response to large-scale atmospheric circulation. Geophys Res Lett 34:L10607, doi:10.1029/2007GL029948

> Daase M, Eiane K (2007) Mesozooplankton distribution in northern Svalbard waters in relation to hydrography. Polar Biol 30:969-981

> Daase M, Vik JO, Bagøien E, Stenseth NC, Eiane K (2007) The influence of advection on Calanus near Svalbard: statistical relations between salinity, temperature and copepod abundance. J Plankton Res 29:903-911

De Robertis A, Higginbottom I (2007) A post-processing technique to estimate the signal-to-noise ratio and remove echosounder background noise. ICES J Mar Sci 64:1282-1291

> Elliott KH, Ricklefs RE, Gaston AJ, Hatch SA, Speakman JR, Davoren GK (2013) High flight costs, but low dive costs, in auks support the biomechanical hypothesis for flightlessness in penguins. Proc Natl Acad Sci USA 110:9380-9384

Falk K, Pedersen CE, Kampp K (2000) Measurements of diving depth in dovekies (Alle alle). Auk 117:522-525

Fauchald P (2009) Spatial interaction between seabirds and prey: review and synthesis. Mar Ecol Prog Ser 391: 139-151
Fauchald P, Erikstad KE, Skarsfjord H (2000) Scale-dependent predator-prey interactions: the hierarchical spatial distribution of seabirds and prey. Ecology 81:773-783

> Fauchald P, Skov H, Skern-Mauritzen M, Hausner VH, Johns D, Tveraa T (2011) Scale-dependent response diversity of seabirds to prey in the North Sea. Ecology 92: 228-239

Fernandes PG, Stewart M (2004) Determining the quality of a multifrequency acoustic identification algorithm. ICES CM 2004:/R:11

Follestad A (1990) The pelagic distribution of little auks Alle alle in relation to a frontal system off central Norway, March/April 1988. Polar Res 8:23-28

Fort J, Cherel Y, Harding AMA, Welcker J and others (2010) Geographical and seasonal variability in the isotopic niche of little auks. Mar Ecol Prog Ser 414:293-302

Gabrielsen GW, Taylor JRE, Konarzewski M, Mehlum M (1991) Field and laboratory metabolism and thermoregulation in dovekies (Alle alle). Auk 108:71-78

> Harding AMA, van Pelt TI, Lifjeld JT, Mehlum F (2004) Sex differences in little auk Alle alle parental care: transition from biparental to paternal-only care. Ibis 146:642-651

> Harding AMA, Hobson KA, Walkusz W, Dmoch K, Karnovsky NJ, Van Pelt TI, Lifjeld JT (2008) Can stable isotope $\left(\delta^{13} \mathrm{C}\right.$ and $\left.\delta^{15} \mathrm{~N}\right)$ measurements of little auk (Alle alle) adults and chicks be used to track changes in highArctic marine foodwebs? Polar Biol 31:725-733

> Harding AMA, Egevang C, Walkusz W, Merkel F, Blanc S, Grémillet D (2009) Estimating prey capture rates of a planktivorous seabird, the little auk (Alle alle), using diet, diving behavior, and energy consumption. Polar Biol 32:785-796

- Henkel LA (2006) Effect of water clarity on the distribution of marine birds in nearshore waters of Monterey Bay, California. J Field Ornithol 77:151-156

> Hop H, Falk-Petersen S, Svendsen H, Kwasniewski S, Pavlov V, Pavlova O, Søreide JE (2006) Physical and biological characteristics of the pelagic system across Fram Strait to Kongsfjorden. Prog Oceanogr 71:182-231

> Hunt GL Jr (1991) Occurrence of polar seabirds at sea in relation to prey concentrations and oceanographic factors. Polar Res 10:553-559

> Hunt GL Jr (1997) Physics, zooplankton, and the distribution of least auklets in the Bering Sea-a review. ICES J Mar Sci 54:600-607

Hunt GL, Schneider DC (1987) Scale-dependent processes in the physical and biological environment of marine birds. In: Croxall JP (ed) Seabirds: feeding biology and role in marine ecosystems. Cambridge University Press, Cambridge

> Hunt GL Jr, Heinemann D, Everson I (1992) Distributions and predator-prey interactions of macaroni penguins, Antarctic fur seals and Antarctic krill near Bird Island, South Georgia. Mar Ecol Prog Ser 86:15-30

> Hunt GL Jr, Coyle KO, Hoffman S, Decker MB, Flint EN (1996) Foraging ecology of short-tailed shearwaters near the Pribilof Islands, Bering Sea. Mar Ecol Prog Ser 141: $1-11$

Hunt GL Jr, Russell RW, Coyle KO, Weingartner T (1998) Comparative foraging ecology of planktivorous auklets in relation to ocean physics and prey availability. Mar Ecol Prog Ser 167:241-259

Hunt GL Jr, Mehlum F, Russell RW, Irons D, Decker MB, Becker PH (1999) Physical processes, prey abundance, and the foraging ecology of seabirds. In: Adams NJ, Slo- 
tow RH (eds) Proc 22th Int Ornithol Congr, Durban. Birdlife South Africa, Johannesburg, p 2040-2056

Ingvaldsen R, Loeng $H$ (2009) Physical oceanography. In: Sakshaug E, Johnsen G, Kovacs K (eds) Ecosystem Barents Sea. Tapir Academic Press, Trondheim, p 33-64

Isaksen K (1995) The breeding population of little auk (Alle alle) in colonies in Hornsund and north western Spitsbergen. In: Isaksen $\mathrm{K}$, Bakken V (eds) Seabird population in the northern Barents Sea. Meddelelser no. 13, Norwegian Polar Institute, Oslo

Jakubas D, Gluchowska M, Wojczulanis-Jakubas K, Karnovsky NJ and others (2011) Foraging effort does not influence body condition and stress level in little auks. Mar Ecol Prog Ser 432:277-290

Jakubas D, Trudnowska E, Wojczulanis-Jakubas K, Iliszko L and others (2013) Foraging closer to the colony leads to faster growth in little auks. Mar Ecol Prog Ser 489: 263-278

> Joiris CR, Falck E (2011) Summer at-sea distribution of little auks Alle alle and harp seals Pagophilus (Phoca) groenlandica in the Fram Strait and the Greenland Sea: impact of small-scale hydrological events. Polar Biol 34:541-548

> Karnovsky NJ, Kwasniewski S, Weslawski JM, Walkusz W, Beszczynska-Möller A (2003) Foraging behaviour of little auks in a heterogeneous environment. Mar Ecol Prog Ser 253:289-303

Karnovsky NJ, Hobson KA, Iverson S, Hunt GL Jr (2008) Seasonal changes in diets of seabirds in the North Water Polynya: a multiple-indicator approach. Mar Ecol Prog Ser 357:291-299

Karnovsky N, Harding AMA, Walkusz W, Kwasniewski S and others (2010) Foraging distributions of little auks (Alle alle) across the Greenland Sea: implications of present and future climate change. Mar Ecol Prog Ser 415:283-293

- Karnovsky NJ, Brown ZW, Welcker J, Harding A and others (2011) Inter-colony comparison of diving behavior of an arctic top predator: implications for warming in the Greenland Sea. Mar Ecol Prog Ser 440:229-240

Kwasniewski S, Gluchowska M, Jakubas D, WojczulanisJakubas K and others (2010) The impact of different hydrographic conditions and zooplankton communities on provisioning little auks along the west coast of Spitsbergen. Prog Oceanogr 87:72-82

Kwasniewski S, Gluchowska M, Walkusz W, Karnovsky NJ and others (2012) Interannual changes in zooplankton on the West Spitsbergen shelf in relation to hydrography and their consequences for the diet of planktivorous seabirds. ICES J Mar Sci 69:890-901

> Ladd C, Jahncke J, Hunt GL Jr, Coyle KO, Stabeno PJ (2005) Hydrographic features and seabird foraging in Aleutian Passes. Fish Oceanogr 14:178-195

> Legendre P, Dale MRT, Fortin MJ, Gurevitch J, Hohn M, Myers D (2002) The consequences of spatial structure for the design and analysis of ecological field surveys. Ecography 25:601-615

Long SJ (1997) Regression models for categorical and limited dependent variables. Sage, Thousand Oaks, CA

MacLennan DN, Fernandes PG, Dalen J (2002) A consistent approach to definitions and symbols in fisheries acoustics. ICES J Mar Sci 59:365-369

- Madureira LSP, Everson I, Murphy EJ (1993) Interpretation of acoustic data at 2 frequencies to discriminate between Antarctic krill (Euphausia superba Dana) and other scatterers. J Plankton Res 15:787-802
Mehlum F, Hunt GL Jr, Klusek Z, Decker MB, Nordlund N (1996) The importance of prey aggregations to the distribution of Brünnich's guillemots in Storfjorden, Svalbard. Polar Biol 16:537-547

> Mehlum F, Hunt GL Jr, Klusek Z, Decker MB (1999) Scaledependent correlations between the abundance of Brünnich's guillemots and their prey. J Anim Ecol 68:60-72

Pakhomov EA, McQuaid CD (1996) Distribution of surface zooplankton and seabirds across the Southern Ocean. Polar Biol 16:271-286

Pianka ER (1986) Ecology and natural history of desert lizards. Analyses of the ecological niche and community structure. Princeton University Press, Princeton, NJ

Piatt JF (1990) The aggregative response of common murres and Atlantic puffins to schools of capelin. Stud Avian Biol 14:36-51

R Development Core Team (2012) R: a language and environment for statistical computing. R Foundation for Statistical Computing, Vienna. www.r-project.org

Ridout M, Demétrio CGB, Hinde J (1998) Models for count data with many zeros. International Biometric Conference, Cape Town

> Rosing-Asvid A, Hedeholm R, Arendt KE, Fort J, Robertson GJ (2013) Winter diet of the little auk (Alle alle) in the Northwest Atlantic. Polar Biol 36:1601-1608

> Russell RW, Hunt GL Jr, Coyle KO, Cooney RT (1992) Foraging in a fractal environment: spatial patterns in a marine predator-prey system. Landscape Ecol 7:195-209

Sakshaug E (2004) Primary and secondary production in the Arctic Seas. In: Stein R, Macdonald RW (eds) The organic carbon cycle in the Arctic Ocean. Springer, Berlin, p 57-81

> Saloranta TM, Svendsen H (2001) Across the Arctic front west of Spitsbergen: high-resolution CTD sections from 1998-2000. Polar Res 20:177-184

Schneider DC (1991) The role of fluid dynamics in the ecology of marine birds. Oceanogr Mar Biol Annu Rev 29: 487-521

Schneider DC, Piatt JF (1986) Scale-dependent correlation of seabirds with schooling fish in a coastal ecosystem. Mar Ecol Prog Ser 32:237-246

Scott CL, Kwasniewski S, Falk-Petersen S, Sargent JR (2000) Lipids and life strategies of Calanus finmarchicus, Calanus glacialis and Calanus hyperboreus in late autumn, Kongsfjorden, Svalbard. Polar Biol 23:510-516

Søreide JE, Falk-Petersen S, Hegseth EN, Hop H, Carroll ML, Hobson KA, Blachowiak-Samolyk K (2008) Seasonal feeding strategies of Calanus in the high-Arctic Svalbard region. Deep-Sea Res II 55:2225-2244

Steen H, Vogedes D, Broms F, Falk-Petersen S, Berge J (2007) Little auks (Alle alle) breeding in a High Arctic fjord system: bimodal foraging strategies as a response to poor food quality? Polar Res 26:118-125

Stempniewicz L (2001) Alle alle little auk. J BWP update, Vol 3. Oxford University Press, Oxford, p 175-201

> Stempniewicz L, Blachowiak-Samolyk K, Weslawski JM (2007) Impact of climate change on zooplankton communities, seabird populations and arctic terrestrial ecosystem-a scenario. Deep-Sea Res II 54:2934-2945

Stempniewicz L, Darecki M, Trudnowska E, BlachowiakSamolyk K and others (2013) Visual prey availability and distribution of foraging little auks (Alle alle) in the shelf waters of West Spitsbergen. Polar Biol 36:949-955

Stephens DW, Krebs JR (1986) Foraging theory. Princeton University Press, Princeton, NJ 
Svendsen H, Beszczynska-Møller A, Hagen JO, Lefauconnier B and others (2002) The physical environment of Kongsfjorden-Krossfjorden, an Arctic fjord system in Svalbard. Polar Res 21:133-166

Swartzman G, Hunt G (2000) Spatial association between murres (Uria spp.), puffins (Fratercula spp.) and fish shoals near Pribilof Islands, Alaska. Mar Ecol Prog Ser 206:297-309

Tasker ML, Jones PH, Dixon T, Blake BF (1984) Counting seabirds at sea from ships: a review of methods employed and a suggestion for a standardized approach. Auk 101:567-577

Trudnowska E, Szczucka J, Hoppe L, Boehnke R, Hop H, Blachowiak-Samolyk K (2012) Multidimensional zooplankton observations on the northern West Spitsbergen Shelf. J Mar Syst 98-99:18-25

Våge S (2007) Structure and dynamics of the Barents Sea Polar Front near the Great Bank and associated plankton distribution in August 2007. MSc thesis, University of Tromsø

Walkusz W, Kwasniewski S, Falk-Petersen S, Hop H, Tverberg V, Wieczorek P, Weslawski JM (2009) Seasonal and spatial changes in the zooplankton community of Kongs- fjorden, Svalbard. Polar Res 28:254-281

Wallace MI, Cottier FR, Brierley AS, Tarling GA (2013) Modelling the influence of copepod behavior on faecal pellet export at high latitudes. Polar Biol 36:579-592

Watkins JL, Brierley AS (1996) A post-processing technique to remove background noise from echo integration data. ICES J Mar Sci 53:339-344

Welcker J, Beiersdorf A, Varpe Ø, Steen H (2012) Mass fluctuations suggest different functions of bimodal foraging trips in a central-place forager. Behav Ecol 23:1372-1378

Weslawski JM, Koszteyn J, Kwasniewski S, Stempniewicz L, Malinga M (1999) Summer food resources of the little auk, Alle alle (L.) in the European Arctic seas. Pol Polar Res 20:387-403

> Wojczulanis-Jakubas K, Jakubas D (2012) When and why does my mother leave me? The question of brood desertion in the dovekie (Alle alle). Auk 129:632-637

Wojczulanis-Jakubas K, Jakubas D, Karnovsky NJ, Walkusz W (2010) Foraging strategy of little auks under divergent conditions on feeding grounds. Polar Res 29:22-29

Zuur AF, Saveliev AA, Ieno EN (2012) Zero inflated models and generalized linear mixed models with R. Highland Statistics, Newburgh

Appendix 1. Zero inflation and spatial autocorrelation

We assessed both potential zero inflation in little auk count data and spatial autocorrelation among the Pearson residuals of the final models.

Zero inflation. Count data are often characterized by an excess of zeros. Zero inflation can potentially lead to over-dispersion and biased model parameters if normal, Poisson, or negative binomial (NB) distributions are used for modelling these data, as considerably fewer zeros are expected for these distributions (Ridout et al. 1998). Little auk count data were potentially zero inflated with $32.6 \%$ zero counts at the $3 \mathrm{~km}$ scale and $12.7 \%$ zero counts at the $12 \mathrm{~km}$ scale. Excess zeros may be 'true zeros' or 'false zeros' (Ridout et al. 1998). True zeros result from birds in fact not being present (e.g. due to unsuitable habitat). False zeros stem from the failure to detect birds that are actually present (observer error). We initially assumed that our data could potentially contain both true and false zeros.

Spatial autocorrelation. We first created histograms of the spatial distances between $3 \mathrm{~km}$ and $12 \mathrm{~km}$ bins, respectively. Based on these histograms, we defined a cut-off value that separated bins into neighbour and non-neighbour bins. Usually, this cut-off value is 5 or $10 \%$ of the maximum distance between the study sites (=bins; Zuur et al. 2012). For our data, the cut-off value was $25 \mathrm{~km}$ at both spatial scales, and, thus, bins separated by $<25 \mathrm{~km}$ were considered as neighbour bins. We then used this cut-off value in the sample variograms to check whether spatial autocorrelation occurred among neighbour bins.
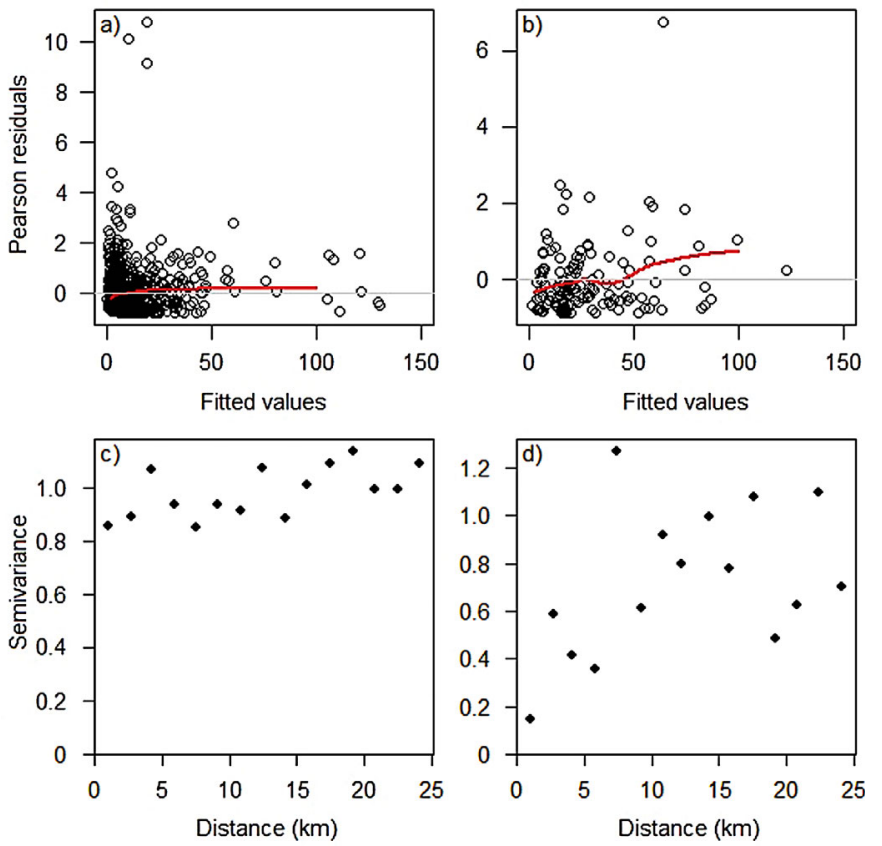

Fig. A1. Model validation with extracted Pearson residuals from the final model (NB GLMM) plotted against fitted values at (a) $3 \mathrm{~km}$, and (b) $12 \mathrm{~km}$ spatial scale, and spatial autocorrelation at (c) $3 \mathrm{~km}$, and (d) $12 \mathrm{~km}$ spatial scale 